\title{
Perbandingan Karakteristik Minuman Probiotik Semangka (Citrullus lanatus) Dengan Variasi Jenis Semangka Merah Dan Kuning Menggunakan Starter Lactobacillus casei Strain Shirota
}

\section{Comparison Of Watermelon (Citrullus lanatus) Probiotic Drinks Characteristics With Red And Yellow Watermelon Using Starter Lactobacillus Casei Shirota Strain}

\author{
Maria Fetty Yuliana Sari ${ }^{1 *}$, Retno Herrani Setyati Catarina ${ }^{1}$ \\ ${ }^{1}$ Program Studi Pendidikan Biologi, Jurusan Pendidikan MIPA, Fakultas Keguruan dan Ilmu Pendidikan, \\ Universitas Sanata Dharma \\ Jl. Affandi, Santren, Caturtunggal, Kec. Depok, Kabupaten Sleman, Daerah Istimewa Yogyakarta, Indonesia \\ Email: mariafys@gmail.com \\ *Penulis untuk korespondensi
}

\begin{abstract}
Watermelon has the potential to be processed into watermelon probiotic beverage products. This study aims to determine: 1)the effects of red and yellow watermelon on watermelon probiotic drinks, 2) which watermelon can produce the highest characteristics, and 3) which watermelon probiotic drinks mostly preferred by panelists. The method used is Completely Randomized Design (CRD). The treatment is done to red and yellow watermelon. The characteristics test and organoleptic results were analyzed with quantitative descriptive methodusing the Independent Sample $T$ Test. The results showed that variations of red and yellow watermelon had significant effect on total BAL and pH test. However it did not significantly affect the sugar total test. Red watermelon produces the highest characteristics with the average total BAL $7.2 \times 10^{4} \mathrm{CFU} / \mathrm{ml}$, total sugar $12.63 \% \mathrm{Brix}$, and pH 5.8. Red watermelon probiotic drink is most preferred by panelists based onthe color aspects of 4.19 , while the yellow watermelon is preferred by panelists based onthe smell aspect of 3.59 and taste 3.92.
\end{abstract}

Keywords: red watermelon, yellow watermelon, Lactobacillus casei strain Shirota, probiotic drink, characteristics test, organoleptic test

\begin{abstract}
Abstrak
Buah semangka berpotensi untuk diolah menjadi minuman probiotik semangka. Penelitian ini bertujuan untuk mengetahui: 1) pengaruh variasi jenis semangka merah dan kuning terhadap karakteristik minuman probiotik semangka, 2) jenis semangka yang dapat menghasilkan karakteristik minuman probiotik tertinggi, dan 3) jenis semangka untuk produk minuman probiotik yang paling disukai oleh panelis. Metode yang digunakan adalah Rancangan Acak Lengkap (RAL). Perlakuan diterapkan ke variasi jenis semangka merah (M) dan kuning (K). Data uji karakteristik dan organoleptik dianalisis secara deskriptif kuantitatif menggunakan uji Independent Sample T-Test. Hasil penelitian menunjukkan variasi jenis semangka merah dan kuning berpengaruh secara signifikan pada uji total BAL dan $\mathrm{pH}$, tetapi tidak berpengaruh secara signifikan pada uji total gula. Semangka merah menghasilkan karakteristik tertinggi dengan rerata nilai total $\mathrm{BAL} 7,2 \times 10^{4} \mathrm{CFU} / \mathrm{ml}$, total gula $12,63 \%$ Brix, dan pH 5,8. Minuman probiotik semangka merah paling disukai oleh panelis dari aspek warna 4,19 (suka), sedangkan semangka kuning paling disukai oleh panelis dari aspek aroma 3,59 (cukup suka) dan rasa 3,92 (cukup suka).
\end{abstract}

Kata kunci: semangka merah, semangka kuning, Lactobacillus casei strain Shirota, minuman probiotik, uji karakteristik, uji organoleptik 


\section{Pendahuluan}

Buah semangka merupakan buah yang banyak mengandung air, rasanya manis, dan renyah. Buah ini tumbuh di daerah tropis termasuk Indonesia. Buah semangka tergolong buah yang populer karena dikenal dan digemari oleh masyarakat karena kesegaran dari daging buahnya. Semangka biasanya dapat dikonsumsi secara langsung atau dibuat menjadi suatu olahan. Berdasarkan warna daging buahnya, ada dua jenis buah semangka yakni semangka merah dan kuning. Buah semangka mudah dijumpai di toko buah karena termasuk buah semusim. Tanaman semangka bersifat semusim karena umur tanam hingga panennya hanya memerlukan waktu 6 bulan.

Ketika masa panen raya tiba, harga jual buah semangka rendah di pasaran. Menurut berita KR Jogja (2019), pada tanggal 27 Januari 2019 harga jual buah semangka di Kebumen ketika musim kemarau Rp 4.000,00 per kilogram, tetapi ketika musim penghujan terjadi penurunan harga menjadi Rp 2.000,00-
2.500,00 per kilogram dari petani. Selain itu, olahan dari buah semangka masih terbatas seperti jus, sup buah, dan salad buah. Salah satu cara untuk mengatasi permasalahan tersebut yaitu dengan mengolah buah semangka menjadi minuman probiotik. Pembuatan minuman probiotik pada umumnya menggunakan bahan utama dari susu sapi yang harganya relatif lebih mahal. Oleh karena itu diperlukan alternatif bahan lain. Salah satu bahan alternatif yang dapat dipilih yakni sari buah. Kelebihan sari buah diantaranya bersifat rendah lemak, kaya serat pangan, kaya akan vitamin, dan memiliki aroma yang menarik (Nurainy dkk., 2018).

Masyarakat pada umumnya lebih menyukai semangka merah daripada kuning karena rasanya yang lebih manis (Pertiwi, 2017). Semangka merah memiliki rasa yang lebih manis dibandingkan semangka kuning. Menurut Sarmin dkk. (2017), berikut ini perbandingan kandungan gula semangka merah dan kuning:

Tabel 1. Perbandingan Kandungan Gula Semangka Merah dan Kuning

\begin{tabular}{cccc}
\hline \hline Jenis Semangka & Fruktosa(mg/g) & Glukosa(mg/g) & Sukrosa(mg/g) \\
\hline Merah & 50 & 29,5 & 35 \\
Kuning & 51 & 34 & 15 \\
\hline \hline
\end{tabular}

Adanya perbedaan tersebut tentunya akan mempengaruhi karakteristik minuman probiotik yang dihasilkan. Pembuatan minuman probiotik dari buah semangka diharapkan dapat menambah nilai jual dan meningkatkan variasi olahan dari buah semangka.

Minuman probiotik merupakan minuman hasil fermentasi asam laktat yang mengandung bakteri asam laktat hidup (Pranayanti dan Aji, 2015). Bakteri yang terkandung dalam minuman probiotik menguntungkan bagi saluran pencernaan. Minuman probiotik dapat menjaga keseimbangan mikroflora usus dengan menekan pertumbuhan bakteri yang merugikan di usus (Utami, 2018). Minuman probiotik memiliki berbagai manfaat bagi kesehatan. Pertama, mencegah lactose intolerance karena memperbaiki pencernaan protein susu dan laktosa. Kedua, mengatasi diare karena dapat menghambat pertumbuhan bakteri patogen di usus. Ketiga, menurunkan kanker kolon dengan meningkatkan aktivitas peristaltik usus untuk mengeluarkan material feses yang mengandung enzim dan karsinogen hasil dari bakteri patogen. Keempat, meningkatkan sistem kekebalan tubuh dengan memperbaiki mikroflora usus. Kelima, melindungi saluran pencernaan karena mempertahankan keseimbangan mikroflora dalam usus agar tetap normal (Widodo, 2017).

Pembuatan minuman probiotik dari buah semangka memanfaatkan bakteri asam laktat yaitu Lactobacillus casei strain Shirota. Bakteri tersebut diharapkan dapat memenuhi kebutuhan probiotik hidup yang bermanfaat bagi tubuh (Pranayanti dan Aji, 2015). Pertumbuhan bakteri asam laktat dalam pembuatan minuman probiotik memerlukan perhatian khusus. Salah satu faktor yang dapat mempengaruhi pertumbuhan bakteri yakni nutrisi. Nutrisi yang harus dipersiapkan yaitu sumber energi (gula). Kandungan gula yang terdapat pada buah semangka merah dan kuning akan dimanfaatkan oleh bakteri sebagai sumber karbon pada proses fermentasi sehingga terbentuk asam laktat (Utami, 2018). 
Berdasarkan Nurainy dkk. (2018) tentang minuman probiotik dari sari buah jambu biji (Psidium guajava) menggunakan persentase penambahan sukrosa $4 \%(\mathrm{w} / \mathrm{v})$ dan waktu fermentasi 48 jam untuk menghasilkan karakteristik terbaik. Berdasarkan penelitian Pranayanti dan Aji (2015) tentang minuman probiotik dari air kelapa muda (Cocos nucifera L.) menggunakan persentase tanpa penambahan sukrosa dan waktu fermentasi 48 jam untuk menghasilkan karakteristik terbaik. Berdasarkan Utami (2018) tentang minuman probiotik dari sari buah salak menggunakan persentase penambahan susu $10 \%$ (v/v) dan waktu fermentasi 8 jam untuk menghasilkan karakteristik terbaik. Oleh karena itu, kebaruan dari penelitian yang akan dilakukan yaitu bahan utama yang digunakan berupa buah semangka merah dan kuning. Penelitian ini melibatkan satu faktor yaitu jenis semangka yang digunakan. Perbedaan kadar gula pada buah semangka merah dan kuning akan menghasilkan minuman probiotik dengan karakteristik yang berbeda.

Tujuan dari penelitian ini mengetahui adanya pengaruh variasi jenis semangka merah dan kuning terhadap karakteristik total BAL, total gula, dan $\mathrm{pH}$ minuman probiotik semangka; mengetahui jenis semangka yang dapat menghasilkan karakteristik total BAL, total gula, dan $\mathrm{pH}$ tertinggi dalam pembuatan minuman probiotik semangka; dan mengetahui jenis semangka untuk produk minuman probiotik semangka yang paling disukai oleh panelis.

\section{Metode Penelitian}

\section{Bahan}

\begin{abstract}
Bahan yang digunakan dalam penelitian ini diantaranya semangka merah dari Yogyakarta, semangka kuning dari Yogyakarta, starter Lactobacillus casei strain Shirota (dari minuman probiotik Yakult), gula pasir (sebagai sukrosa), alkohol $70 \%$, tisu, kertas payung, karet, plastik bening dan akuades.
\end{abstract}

\footnotetext{
Alat

Alat yang digunakan dalam penelitian ini diantaranya pisau, blender, baskom, sendok, panci, talenan, saringan santan, kain saring, botol kaca, timbangan kue, gelas
}

corong ukur, gelas plastik kecil, gelas minum, gelas beker, pipet tetes, termometer, kulkas, $\mathrm{pH}$ meter (HANNA instruments), refraktometer (HANNA instruments), autoklaf, kompor gas, alat tulis, dan kamera.

\section{Pelaksanaan Penelitian}

\section{a. Pembuatan Sari Buah Semangka}

Buah semangka yang dipilih dalam kondisi segar dan baik. Buah semangka merah maupun kuning dipotong kecil-kecil dan ditimbang sebanyak 1.350 gram untuk 3 pengulangan. Buah semangka dihaluskan tanpa ditambah air hingga menjadi jus. Jus buah semangka disaring menggunakan saringan santan dan kain saring hingga diperoleh sari buah semangka. Kadar gula dan nilai $\mathrm{pH}$ awal diukur menggunakan refraktometer digital dan $\mathrm{pH}$ meter digital.

\section{b. Pembuatan Minuman Probiotik Semangka}

Sari buah semangka diberi tambahan gula dengan konsentrasi $4 \% \quad(\mathrm{w} / \mathrm{v})$ dan dipasteurisasi pada suhu $70^{\circ} \mathrm{C}$ selama \pm 10 menit. Sari buah semangka dimasukkan dalam botol kaca steril dengan volume masing-masing $400 \mathrm{ml}$ dan ditutup tidak terlalu rapat. Sari buah semangka didinginkan sampai suhu $31-32^{\circ} \mathrm{C}$. Sari buah semangka diinokulasikan dengan starter Lactobacillus casei strain Shirota (dari minuman probiotik Yakult) sebanyak $4 \%(\mathrm{v} / \mathrm{v})$ dan diinkubasi pada suhu $37^{\circ} \mathrm{C}$ selama 8 jam. Minuman probiotik semangka dimasukkan ke dalam kulkas.

\section{Karakterisasi dan Uji Organoleptik Minuman Probiotik Semangka}

Karakterisasi minuman probiotik semangka meliputi uji total bakteri asam laktat (BAL), total gula, dan nilai $\mathrm{pH}$. Pengujian total BAL dengan metode TPC (Total Plate Counting) (Raharjo, 2017). Pengujian total gula dengan menggunakan refraktometer (HANNA instruments)yang telah dikalibrasi (AOAC, 1995). Pengujian nilai $\mathrm{pH}$ dengan menggunakan $\mathrm{pH}$ meter digital merk (HANNA instruments)yang telah dikalibrasi (AOAC, 1995). Uji organoleptik meliputi aspek kesukaan warna, aroma, dan rasa pada minuman probiotik semangka. 


\section{Analisis Data dan Statistik}

Penelitian ini menggunakan Rancangan Acak Lengkap (RAL) dengan satu faktor. Faktor tersebut yaitu variasi jenis semangka yang terdiri dari semangka merah dan kuning. Pengulangan dilakukan sebanyak 3 kali untuk setiap perlakuan sehingga diperoleh 6 percobaan tanpa perlakuan kontrol. Data hasil uji karakteristik yang diperoleh dianalisis menggunakan uji Independent Sample T Test jika data berdistribusi normal. Jika data tidak berdistribusi normal dilakukan uji ManWhitney U. Data hasil uji organoleptik dianalisis menggunakan uji penerimaan produk dengan metode Hedonic Scalling Scoring (1-5 = sangat tidak suka - sangat suka).

\section{Hasil dan Pembahasan}

\section{Karakteristik Minunman Probiotik Semangka}

Berdasarkan hasil penelitian diperoleh perubahan total $\mathrm{BAL}$, total gula, dan $\mathrm{pH}$ yang disajikan pada Tabel 2.

Tabel 2. Karakteristik Minuman Probiotik Semangka

\begin{tabular}{cccccccc}
\hline \hline \multirow{2}{*}{$\begin{array}{c}\text { Jenis } \\
\text { Semangka }\end{array}$} & $\begin{array}{c}\text { Total BAL } \\
(\text { CFU/ml) }\end{array}$ & $\begin{array}{c}\text { Total } \\
\text { Gula } \\
(\% \text { Brix })\end{array}$ & $\begin{array}{c}\text { Total } \\
\text { pH }\end{array}$ & $\begin{array}{c}\text { Total } \\
\text { Gula } \\
(\% \text { Brix })\end{array}$ & $\begin{array}{c}\text { Total } \\
\text { pH }\end{array}$ & $\begin{array}{c}\text { Total Gula } \\
(\% \text { Brix })\end{array}$ & Total pH \\
\hline \hline M & $7,2 \times 10^{4}$ & 8,23 & 5,2 & 13,10 & 5,9 & 12,63 & 5,8 \\
K & $4,6 \times 10^{4}$ & 7,57 & 4,9 & 13,00 & 5,0 & 11,67 & 4,6 \\
\hline \hline
\end{tabular}

Keterangan:M = Semangka merah, $\mathrm{K}=$ Semangka kuning

\section{Total BAL}

Probiotik semangka merah menghasilkan jumlah bakteri asam laktat yang lebih banyak $\left(7,2 \times 10^{4} \mathrm{CFU} / \mathrm{ml}\right)$ dibandingkan dengan minuman probiotik semangka kuning $\left(4,6 \times 10^{4} \mathrm{CFU} / \mathrm{ml}\right)$. Hal tersebut dikarenakan total gula awal pada semangka merah lebih tinggi dibandingkan semangka kuning (Tabel 2).

Jumlah bakteri asam laktat yang tumbuh pada minuman probiotik semangka (Citrullus lanatus) dapat dipengaruhi oleh ketersediaan substrat dalam medium misalnya sukrosa. Jika sukrosa yang terdapat dalam medium optimal, maka proses perombakan substrat yang akan menghasilkan energi untuk perkembangbiakan sel akan semakin tinggi (Pranayanti dan Aji, 2015).

Faktor lain yang dapat mempengaruhi pertumbuhan bakteri asam laktat yaitu suhu fermentasi dan $\mathrm{pH}$. Menurut Ayuti dkk. (2016), suhu optimum untuk pertumbuhan bakteri Lactobacillus casei adalah $30-37^{\circ} \mathrm{C}$. Menurut Nurainy dkk. (2018), rentang pH yang tidak menghambat pertumbuhan bakteri Lactobacillus casei adalah 3,0-6,0.
Bakteri asam laktat terbukti mampu hidup dalam medium berbahan buah seperti semangka dan buah lainnya, namun belum ada SNI yang diterbitkan mengenai minuman fermentasi buah nonsusu. SNI yang telah ada yaitu tentang Yoghurt dan Minuman Susu Fermentasi Berperisa. SNI 10-2981-2009 menyatakan syarat minuman yoghurt yaitu mengandung total BAL minimal $1,0 \times 10^{7}$ CFU/ml. SNI 7552-2009 menyatakan syarat minuman susu fermentasi berperisa yaitu mengandung total BAL minimal $1,0 \times 10^{6}$ $\mathrm{CFU} / \mathrm{ml}$.

Analisis statistik Man-Whitney menunjukkan bahwa 0,046 ( $<<0,05)$, sehingga terdapat perbedaan yang signifikan dari perlakuan yang diberikan. Jenis semangka berpengaruh secara signifikan terhadap total bakteri asam laktat pada minuman probiotik semangka.

\section{Total Gula}

Semangka merah dikenal memiliki rasa yang lebih manis dibandingkan semangka kuning. Rerata kadar gula untuk minuman probiotik semangka merah setelah fermentasi yaitu $12,63 \%$ Brix, sedangkan untuk minuman probiotik semangka kuning yaitu 11,67\% Brix. 
Tabel 3. Persentase Peningkatan dan Penurunan Kadar Gula

\begin{tabular}{|c|c|c|c|c|c|c|c|}
\hline \multirow[b]{2}{*}{$\begin{array}{c}\text { Jenis } \\
\text { Semangka }\end{array}$} & \multirow[b]{2}{*}{$\begin{array}{c}\text { Total Gula Awal } \\
\text { (\% Brix) }\end{array}$} & \multicolumn{2}{|c|}{ Peningkatan } & \multicolumn{3}{|c|}{ Penurunan } & \multirow[b]{2}{*}{$\%$} \\
\hline & & $\begin{array}{l}\text { Total Gula } \\
\text { Sebelum } \\
\text { Fermentasi } \\
(\% \text { Brix })\end{array}$ & $\Delta \mathbf{1}$ & $\%$ & $\begin{array}{c}\text { Total Gula } \\
\text { Setelah } \\
\text { Fermentasi } \\
(\% \text { Brix })\end{array}$ & $\Delta 2$ & \\
\hline$\overline{\mathrm{M}}$ & 8,23 & 13,10 & 4,87 & "59,17 & 12,63 & 0,47 & 3,59 \\
\hline $\mathrm{K}$ & 7,57 & 13,00 & 5,43 & 71,73 & 11,67 & 1,33 & 10,23 \\
\hline
\end{tabular}

Keterangan:M = Semangka merah, $\mathrm{K}=$ Semangka kuning, $\Delta 1$ = Total gula sebelum fermentasi - Total gula awal,

$\Delta 2=$ Total gula sebelum fermentasi - Total gula setelah fermentasi

Penurunan rerata kadar gula dikarenakan pada proses fermentasi terjadi metabolisme bakteri yang menggunakan sukrosa sebagai nutrisi pertumbuhannya. Menurut Sarmin dkk. (2017), semangka mengandung gula berupa sukrosa, fruktosa, dan glukosa. Semua gula dapat dimanfaatkan oleh Lactobacillus casei sebagai sumber energi. Sukrosa merupakan salah satu jenis gula yang dapat dimetabolisme oleh bakteri asam laktat menjadi asam laktat selama proses fermentasi (Elsaputra dkk., 2016).

Sukrosa yang merupakan disakarida dari karbohidrat akan dipecah terlebih dahulu oleh bakteri Lactobacillus casei menjadi monosakarida menggunakan enzim ekstraseluler amilase penyusunnya yaitu glukosa dan fruktosa (Nurainy dkk., 2018). Glukosa akan dimanfaatkan oleh bakteri Lactobacillus casei sebagai sumber energi melalui fermentasi homofermentatif. Menurut Utami (2018), bakteri Lactobacillus casei termasuk bakteri homofermentatif.

Penurunan kadar gula pada semangka kuning yang lebih besar (10,23\%)dibandingkan semangka merah $(3,59 \%)$ menunjukkan bahwa ketersediaan gula dalam medium semakin menurun. Menurut Pranayanti dan Aji (2015), ketika ketersediaan substrat menurun menyebabkan bakteri asam laktat tidak aktif untuk memperbanyak diri. Selain itu, penurunan jumlah sel bakteri dapat terjadi akibat dihasilkannya metabolit sampingan seperti hidrogen peroksida yang dalam akumulasi tertentu dapat menghambat pertumbuhan bakteri itu sendiri.

Sukrosa yang merupakan disakarida dari karbohidrat akan dipecah terlebih dahulu oleh bakteri Lactobacillus casei menjadi monosakarida menggunakan enzim ekstraseluler amilase penyusunnya yaitu glukosa dan fruktosa (Nurainy dkk., 2018). Glukosa akan dimanfaatkan oleh bakteri Lactobacillus casei sebagai sumber energi melalui fermentasi homofermentatif. Menurut Utami (2018), bakteri Lactobacillus casei termasuk bakteri homofermentatif.

Analisis statistikIndependent Sample T Test menunjukkan bahwa $0,125(\mathrm{p}>0,05)$ dan $0,171 \quad(p>0,05)$, sehingga tidak terdapat perbedaan yang signifikan dari perlakuan yang diberikan. Jenis semangka tidak berpengaruh secara signifikan terhadap total gula setelah proses fermentasi pada minuman probiotik semangka.

\section{pH Minuman Probiotik}

Rerata nilai $\mathrm{pH}$ untuk minuman probiotik semangka merah setelah fermentasi yaitu 5,8 . Sedangkan untuk minuman probiotik semangka kuning yaitu 4,6. Menurut Nurainy dkk. (2018), rentang pH yang tidak menghambat pertumbuhan bakteri Lactobacillus casei adalah 3,0-6,0. Menurut Hasruddin dan Nanda (2015), pH optimal untuk produksi asam laktat adalah 5,0-7,0.

Tabel 4. Persentase Peningkatan dan Penurunan Nilai pH

\begin{tabular}{|c|c|c|c|c|c|c|c|}
\hline \multirow[b]{2}{*}{ Jenis Semangka } & \multirow[b]{2}{*}{$\begin{array}{c}\text { pH } \\
\text { Awal }\end{array}$} & \multicolumn{2}{|c|}{ Peningkatan } & \multirow[b]{2}{*}{$\%$} & \multicolumn{2}{|c|}{ Penurunan } & \multirow[b]{2}{*}{$\%$} \\
\hline & & $\begin{array}{l}\text { pH Sebelum } \\
\text { Fermentasi } \\
\end{array}$ & $\Delta \mathbf{1}$ & & $\begin{array}{l}\text { pH Setelah } \\
\text { Fermentasi }\end{array}$ & $\Delta 2$ & \\
\hline$\overline{\mathrm{M}}$ & 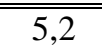 & 5,5 & 0,7 & 1013,46 & 5,8 & 0,1 & 1,70 \\
\hline $\mathrm{K}$ & 4,6 & 5,0 & 0,4 & 8,70 & 4,6 & 0,4 & 8,00 \\
\hline
\end{tabular}

Keterangan:M = Semangka merah, $\mathrm{K}=$ Semangka kuning, $\Delta 1=\mathrm{pH}$ sebelum fermentasi $-\mathrm{pH}$ awal, $\Delta 2=\mathrm{pH}$ sebelum fermentasi $-\mathrm{pH}$ setelah fermentasi 
Tabel 4 menunjukkanpenurunan nilai $\mathrm{pH}$ pada minuman probiotik semangka kuning lebih besar yaitu $8,00 \%$. Sedangkan pada minuman probiotik semangka merah sebesar $1,70 \%$. Penurunan nilai $\mathrm{pH}$ berkaitan dengan penurunan kadar gula setelah fermentasi. Meskipun penurunan kadar gula pada minuman probiotik semangka kuning lebih besar, namun pertumbuhan bakteri asam laktat cenderung lebih sedikit (lihat Tabel 2) akibat dihasilkannya metabolit sampingan yang menghambat pertumbuhan bakteri.

Menurut Hasruddin dan Nanda (2015), penurunan $\mathrm{pH}$ merupakan salah satu akibat dari proses fermentasi yang terjadi karena adanya akumulasi asam laktat sebagai produk utama dari bakteri homofermentatif melalui jalur EMP (Embden Meyerhof-Parnas). Glukosa akan dipecah menjadi asam piruvat melalui jalur EMP menjadi asam laktat. Asam laktat yang dihasilkan akan disekresikan keluar dari sel bakteri, kemudian terakumulasi dalam medium fermentasi sehingga nilai $\mathrm{pH}$ produk minuman probiotik semangka menjadi menurun.
Analisis statistikIndependent Sample T Test menunjukkan bahwa $0,000(\mathrm{p}<0,05)$ dan $0,001(p<0,05)$, sehingga terdapat perbedaan yang signifikan dari perlakuan yang diberikan. Jenis semangka berpengaruh secara signifikan terhadap nilai $\mathrm{pH}$ setelah proses fermentasi pada minuman probiotik semangka.

\section{Uji Organoleptik Minuman Probiotik Semangka}

Uji organoleptik dilakukan terhadap 25 orang panelis semi terlatih. Analisis organoleptik dilakukan menggunakan uji penerimaan produk dari segi kesukaan warna, aroma, dan rasa dengan metode Hedonic Scalling Scoring $(1-5=$ sangat tidak suka sangat suka). Berikut ini merupakan produk minuman probiotik semangka yang telah dihasilkan (Gambar 4).

Gambar 4 menunjukkan minuman probiotik semangka merah dan kuning yang difermentasi selama 8 jam. Warna minuman yang dihasilkan sesuai dengan warna bahan baku yaitu merah dan kuning. Aroma minuman yang dihasilkan sesuai dengan aroma bahan baku. Rasa minuman yang dihasilkan yaitu manis dan sedikit asam.

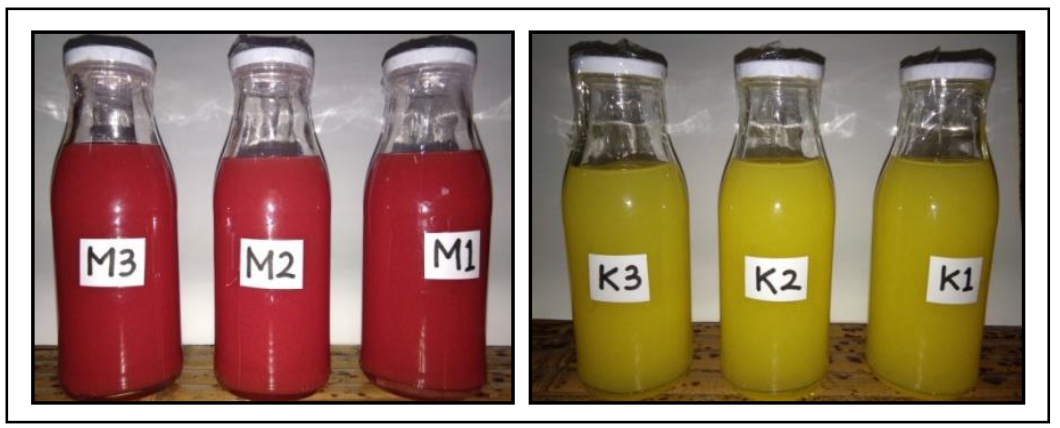

Gambar 4. Minuman Probiotik Semangka Merah dan Kuning

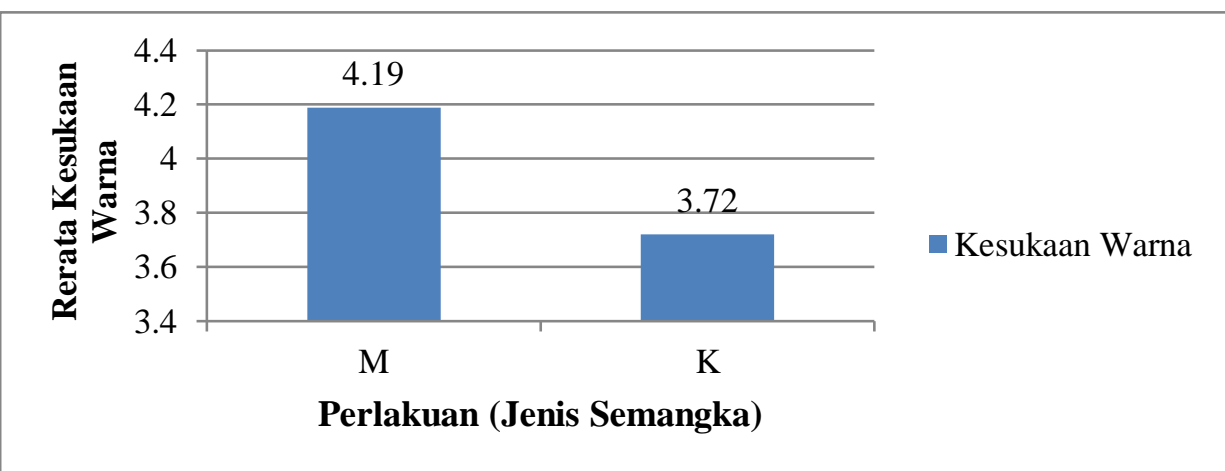

Gambar 5. Rerata Tingkat Kesukaan Panelis terhadap Warna Minuman Probiotik Semangka. Keterangan: $M=$ Semangka merah, $\mathrm{K}=$ Semangka kuning. 


\section{Kesukaan Warna}

Minuman probiotik semangka merah dan kuning menghasilkan warna yang sesuai dengan bahan baku. Minuman probiotik semangka merah berwarna merah. Sedangkan minuman probiotik semangka kuning berwarna kuning. Gambar 4 menunjukkan panelis lebih menyukai warna minuman probiotik semangka merah sebesar 4,19 (suka), dibandingkan minuman probiotik semangka kuning sebesar 3,72 (cukup suka). Menurut CNN (2015), makanan yang berwarna merah akan meningkatkan selera makan seseorang sehingga lebih menarik.

Warna yang dihasilkan pada minuman probiotik semangka dapat dipengaruhi oleh komponen penyusun dalam bahan (Utami, 2018). Semangka merah memiliki daging buah berwarna merah yang berasal dari senyawa pigmen likopen. Sedangkan semangka kuning memiliki daging buah berwarna kuning yang berasal dari senyawa pigmen beta-karoten (Mayasari dkk., 2018). Likopen maupun betakaroten termasuk senyawa karotenoid. Karotenoid merupakan pigmen alami dan dikenal secara luas dari warnanya terutama warna kuning, orange, dan merah (Elsaputra dkk., 2016).

Analisis statistik Independent Sample T Test menunjukkan bahwa $0,004(\mathrm{p}<0,05)$ dan $0,005(\mathrm{p}<0,05)$, sehingga terdapat perbedaan yang signifikan dari perlakuan yang diberikan. Jenis semangka berpengaruh secara signifikan terhadap tingkat kesukaan panelis terhadap warna minuman probiotik semangka.

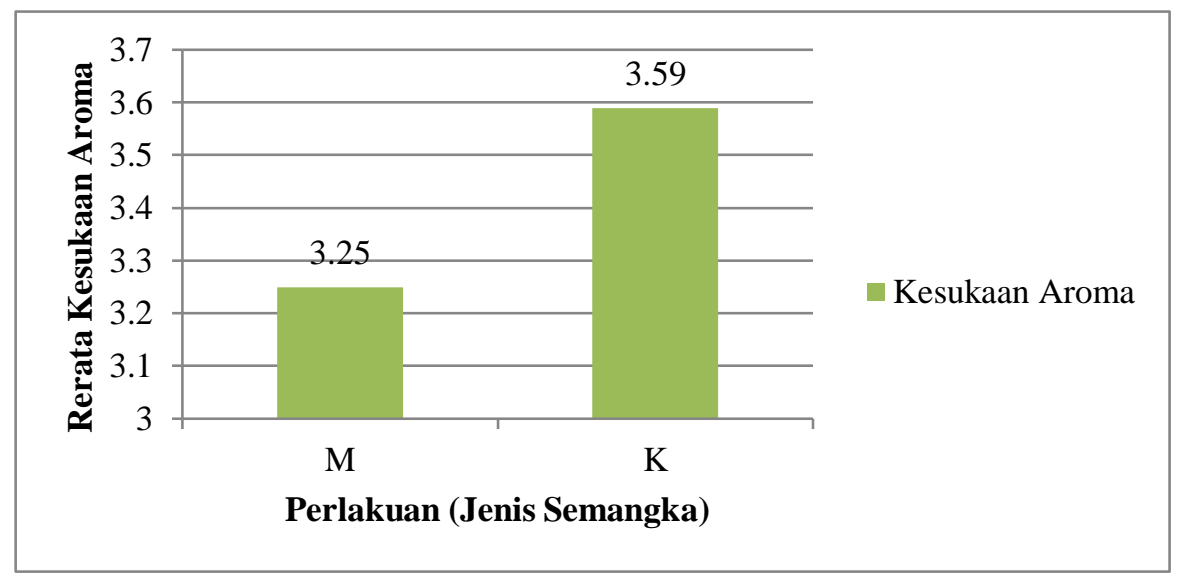

Gambar 6.Tingkat Kesukaan Panelis terhadap Aroma Minuman Probiotik Semangka. Keterangan: $M=$ Semangka merah, $\mathrm{K}=$ Semangka kuning

\section{Aroma}

Minuman probiotik semangka merah dan kuning menghasilkan aroma yang khas sesuai dengan bahan baku. Gambar 5 menunjukkan panelis lebih menyukai aroma minuman probiotik semangka kuning sebesar 3,59 (cukup suka), dibandingkan minuman probiotik semangka merah sebesar 3,25 (cukup suka). Minuman probiotik semangka kuning memiliki aroma yang tidak terlalu menyengat. Perbedaan aroma yang dihasilkan pada kedua produk minuman probiotik semangka dipengaruhi oleh jumlah bakteri asam laktat. Jumlah bakteri asam laktat pada minuman probiotik semangka kuning lebih sedikit dibandingkan dengan minuman probiotik semangka merah (Gambar 1).
Menurut Pranayanti dan Aji (2015), aroma khas produk probiotik diperoleh juga dari asam laktat sebagai hasil metabolisme bakteri yang dapat memberikan ketajaman rasa. Bakteri asam laktat memiliki fungsi utama dalam produk fermentasi yaitu menghasilkan asam laktat yang memberi rasa asam dan menurunkan $\mathrm{pH}$ pada titik dimana bakteri penghasil aroma memproduksi asam volatil secara maksimum. Senyawa volatil dapat meningkatkan kesukaan aroma minuman probiotik semangka. Menurut Pino dkk. (2003), senyawa volatil yang terdapat dalam semangka yaitu ethyl acetate, acetaldehyde, tetradecanoic acid, dan methyl acetate.

Analisis statistikIndependent Sample T Test menunjukkan bahwa $0,036(\mathrm{p}<0,05)$ dan $0,055(\mathrm{p}>0,05)$, sehingga terdapat perbedaan 
yang signifikan dari perlakuan yang diberikan. Jenis semangka berpengaruh secara signifikan terhadap tingkat kesukaan panelis terhadap aroma minuman probiotik semangka.

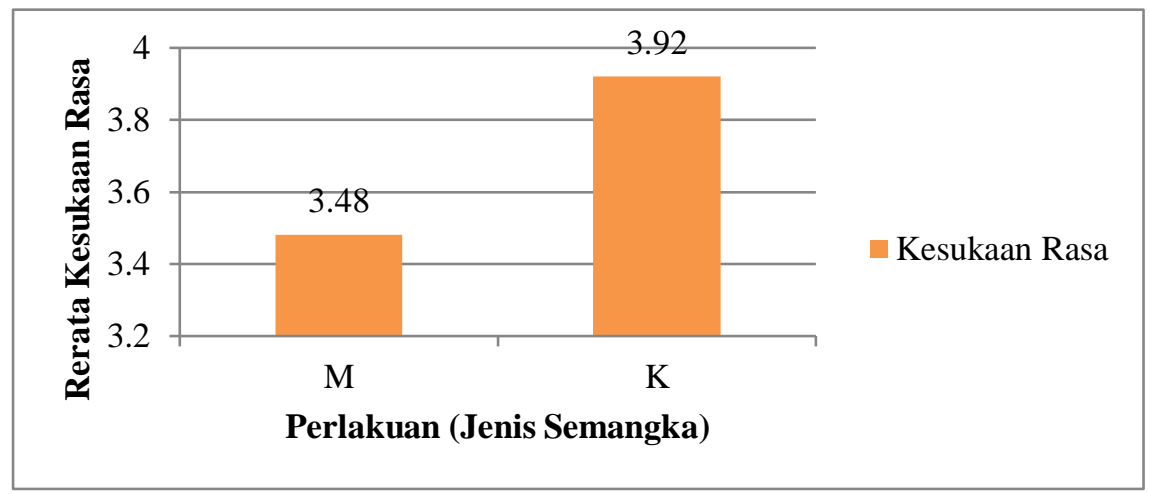

Gambar 7.Rerata Tingkat Kesukaan Panelis terhadap Rasa Minuman Probiotik Semangka. Keterangan: $M=$ Semangka merah, $\mathrm{K}=$ Semangka kuning

\section{Rasa}

Minuman probiotik semangka merah dan kuning menghasilkan rasa yang khas yaitu manis dan agak asam. Gambar 6 menunjukkan panelis lebih menyukai rasa minuman probiotik semangka kuning sebesar 3,92 (cukup suka), dibandingkan minuman probiotik semangka merah sebesar 3,48 (cukup suka). Menurut Utami (2018), selama fermentasi terjadi pembentukan asam laktat yang secara tidak langsung akan berdampak pada penurunan $\mathrm{pH}$ dan akan memberikan cita rasa khas pada produk fermentasi.

Analisis statistik Man-Whitney Umenunjukkan bahwa 0,043 ( $<<0,05)$, sehingga terdapat perbedaan yang signifikan dari perlakuan yang diberikan. Jenis semangka berpengaruh secara signifikan terhadap tingkat kesukaan panelis terhadap rasa minuman probiotik semangka.

\section{Penentuan Perlakuan Terbaik}

Minuman probiotik semangka yang terbaik berdasarkan uji karakteristik yang meliputi uji total BAL, total gula, dan $\mathrm{pH}$ adalah minuman probiotik semangka merah dengan nilai total BAL $7,2 \times 10^{4} \mathrm{CFU} / \mathrm{ml}$, total gula $12,63 \%$ Brix, dan $\mathrm{pH} 5,8$. Sedangkan minuman probiotik semangka yang terbaik berdasarkan uji organoleptik aspek kesukaan warna adalah minuman probiotik semangka merah dengan perolehan rerata untuk kesukaan warna 4,19 (suka). Untuk aspek aroma dan rasa adalah minuman probiotik semangka kuning dengan perolehan rerata untuk kesukaan aroma 3,59 (cukup suka) dan kesukaan rasa 3,92 (cukup suka).

\section{Simpulan}

Variasi jenis semangka (yaitu semangka merah dan kuning) yang digunakan dalam penelitian berpengaruh secara signifikan terhadap karakteristik minuman probiotik semangka yaitu pada uji total BAL $(0,046$ $(\mathrm{p}<0,05))$ dan uji $\mathrm{pH} \quad(0,000 \quad(\mathrm{p}<0,05)$ dan $0,001 \quad(\mathrm{p}<0,05))$, tetapi tidak berpengaruh secara signifikan pada uji total gula $(0,125$ $(p>0,05)$ dan 0,171 ( $p>0,05))$.Jenis semangka merah dapat menghasilkan karakteristik tertinggi dalam pembuatan minuman probiotik semangka dengan rerata nilai total BAL 7,2 x $10^{4} \mathrm{CFU} / \mathrm{ml}$, total gula $12,63 \%$ Brix, dan $\mathrm{pH}$ 5,8.Jenis semangka untuk produk minuman probiotik semangka yang paling disukai oleh panelis yaitu semangka merah dari aspek kesukaan warna 4,19 (suka), sedangkan semangka kuning dari aspek kesukaan aroma 3,59 (cukup suka) dan kesukaan rasa 3,92 (cukup suka).

\section{Ucapan Terima Kasih}

Ucapan terima kasih disampaikan kepada Universitas Sanata Dharma Yogyakarta dan CV. Che-Mix Pratama yang telah memfasilitasi dan membantu menyediaka sraana dan prasarana sehingga penelitian ini berjalan dengan lancar. 


\section{Daftar Pustaka}

AOAC. 1995. Official Methods of Analisys Chemist. Vol. 1A. Washington: AOAC Inc.

Ayuti, Siti Rani, Nurliana, Yurliasni, Sugito, dan Darmawi. 2016. Dinamika Pertumbuhan Lactobacillus casei dan Karakteristik Susu Fermentasi Berdasarkan Suhu dan Lama Penyimpanan. Jurnal Agripet. Vol. 16. No. 1.

CNN. 2015. Alasan Makanan Berwarna Merah Lebih Menggugah Selera. CNN Indonesia. 28 Mei 2015.

Elsaputra, Usman Pato, dan Rahmayuni. 2016. Pembuatan Minuman Probiotik Berbasis Kulit Nanas (Ananas comosus (L.) Merr.) Menggunakan Lactobacillus casei subsp. casei R-68 yang Diisolasi dari Dadih. Jurnal Jom Faperta. Vol. 3. No. 1.

Hasruddin dan Nanda Pratiwi. 2015. Mikrobiologi Industri. Bandung: Alfabeta.

KR Jogja. 2019. Sulit Dipasarkan, Harga Semangka di Kebumen Jatuh. Koran KR Jogja. 28 Januari 2019.

Mayasari, Dian, Vany Bernadus, Nelly Angela, dan Yanti. 2018. Menilik Perbedaan Semangka Kuning dan Merah bagi Kesehatan. Diakses pada tanggal 21 Mei 2019 pukul 21.50 WIB dari https://www.google.com/amp/s/dokters ehat.com/semangka-merah-dankuning-ternyata-memiliki-manfaatyang-berbeda-lho/amp/

Nurainy, Fibra, Samsul Rizal, Suharyono Suharyono, dan Ekariza Umami. 2018. Karakteristik Minuman Probiotik Jambu Biji (Psidium guajava) pada Berbagai Variasi Penambahan Sukrosa dan Susu Skim. Jurnal Aplikasi Teknologi Pangan. Vol. 7. No. 2.

Raharjo, Slamet. 2017. TPC. Diakses pada tanggal 1 Maret 2019 pukul 07.00 WIB dari http://www.infolaborat.com/2017/04/to tal-plate-count.html? $m=1$

Pertiwi, Triroessita Intan. 2017. Banyak yang Nggak Sadar Ternyata Seperti Ini Perbedaan Manfaat Semangka Merah dan Kuning!. Diakses pada tanggal 14 Februari 2019 pukul 13.11 WIB dari http://style.tribunnews.com/amp/2017/ 08/27/banyak-yang-nggak-sadar- ternyata-seperti-ini-perbedaan-

manfaat-semangka-merah-dan-kuning

Pino, Jorge A., Rolando Marbot, dan Juan Aguero. 2003. Volatile Components of Watermelon (Citrullus lanatus [Thunb.] Matsum. et Nakai) Fruit. Jurnal Essensial Oil Research. Vol. 15. No. 6.

Pranayanti, Ida Ayu Pratiharavia dan Aji Sutrisno. 2015. Pembuatan Minuman Probiotik Air Kelapa Muda(Cocos nucifera L.)dengan Starter Lactobacillus casei strain Shirota. Jurnal Pangan dan Agroindustri. Vol. 3. No. 2.

Sarmin, Sabeetha, Amin Ismail, dan Barakatun Nisak Mohammad Yusof. 2017. Physico-Chemical Characteristics of Watermelon in Malaysia. Jurnal Trop. Agric. and Fd. Sc. Vol. 45. No. 2.

SNI (Standar Nasional Indonesia) 10-2981-2009. Yoghurt. Jakarta: Badan Standarisasi Nasional.

SNI (Standar Nasional Indonesia) 7552-2009. Minuman Susu Fermentasi Berperisa. Jakarta: Badan Standarisasi Nasional.

Utami, Cahyaning Rini. 2018. Karakteristik Minuman Probiotik Fermentasi Lactobacillus casei dari Sari Buah Salak. Jurnal Teknologi Pangan. Vol. 9. No. 1.

Widodo dan Tiyas Tono Taufiq. 2017. Bakteri Asam Laktat Strain Lokal. Yogyakarta: Gadjah Mada University Press. 